\title{
Репрессии против комсомола Калмыкии во 2-й половине 1930-х гг.
}

\section{Баатр Андреевич Оконов ${ }^{1}$}

\author{
${ }^{1}$ Калмыцкий научный центр РАН (д. 8, ул. И. К. Илишкина, 358000 Элиста, Российская \\ Федерация) \\ научный сотрудник \\ D 0000-0001-8568-4330.E-mail: vostok80@mail.ru \\ (C) КалмНЦ РАН, 2020 \\ (C) Оконов Б. А., 2020
}

Аннотация. Исследование посвящено рассмотрению репрессий против комсомольской организации Калмыкии в конце 1930-х гг. На основе архивных материалов Калмыцкой АССР исследован весьма сложный период в развитии областной организации ВЛКСМ, в частности политические репрессии. С момента основания комсомольские организации на регулярной основе подвергались чисткам. Официально эти меры преподносились как необходимые для улучшения состава, укрепления рядов, повышения активности в строительстве нового общества. Материалы IV Пленума ЦК ВЛКСМ и XIV Калмыцкой областной конференции ВЛКСМ показали, что репрессиям подверглись непосредственно руководство и актив комсомола. Цель статьи - проанализировать процесс репрессий против актива и руководства комсомолом в Калмыкии в 1937 г. Материаль и методы. Источниковую базу исследования составили как неопубликованные документы из Национального архива Республики Калмыкия (фонд П-22 - архив Калмыцкого обкома ВЛКСМ), так и опубликованные материалы по данной теме. В работе использовались исторические методы: хронологический и проблемно-хронологический, которые позволили выделить особенности репрессивной политики в отношении комсомольцев Калмыкии. Результаты и выводы. Политические репрессии в Калмыкии по отношению к комсомольцам в 1930-е гг. были непосредственно связаны с репрессиями партийно-государственной и хозяйственной номенклатуры автономии. Признав свое «участие в буржуазно-националистической организации», члены Калмыцкого обкома ВКП(б) и обкома ВЛКСМ положили начало массовым чисткам в своих рядах.

Ключевые слова: Калмыцкая автономная область, советская власть, ВЛКСМ, история политических репрессий

Благодарность. Исследование проведено в рамках государственной субсидии — проект «Комплексное исследование процессов общественно-политического и культурного развития народов Юга России» (номер госрегистрации: АААА-А19-119011490038-5). Для цитирования: Оконов Б. А. Репрессии против комсомола Калмыкии во 2-й половине 1930-х гг. // Монголоведение. 2020. Т. 12. № 3. С. 384-397. DOI: 10.221-62/25001523-2020-2-384-397 


\title{
Repression against Kalmykia's Komsomol Activists in the Late 1930s
}

\section{Baatr A. Okonov ${ }^{1}$}

\author{
${ }^{1}$ Kalmyk Scientific Center of the RAS (8, Ilishkin St., Elista 358000, Russian Federation) \\ Research Associate \\ (iD) 0000-0001-8568-4330. E-mail: vostok80@mail.ru
}

\author{
(C) KalmSC RAS, 2020 \\ (C) Okonov B. A., 2020
}

\begin{abstract}
Introduction. The paper deals with repressions against Kalmykia's Komsomol in the late 1930. It examines archival materials of the Kalmyk ASSR, and explores a definitely troubled period in the development of the regional organization of All-Union Leninist Young Communist League. From the earliest days Komsomol communities had been regularly cleansed. In official discourse, such measures were interpreted as essentials aimed to exclude unreliable individuals, improve community cohesion, and facilitate further Socialist construction activities. According to documents issued by the $4^{\text {th }}$ Plenary Assembly of Komsomol Central Committee and $14^{\text {th }}$ Kalmyk Oblast Komsomol Conference, those were Komsomol executives and activists who were actually repressed. Goals. The article aims to analyze the repressive procedures initiated. Materials and Methods. Considered are unpublished documents held by National Archive of Kalmykia (Collection П-22 archives of Kalmyk Oblast Komsomol Committee), and some other published materials. The work employs the chronological and problem-chronological research methods that proved instrumental in identifying features specific for repressive measures against local Komsomol members. Results and Conclusions. The 1930s political repressions against Komsomol in Kalmykia were directly related to ones against party-state and economic executives of the region. Admitting to 'have participated in a bourgeois-nationalist organization', Communist and Komsomol executives gave rise to further mass and dramatic cleanses.
\end{abstract}

Keywords: Kalmyk Autonomous Oblast, Soviets, Komsomol, history of political repressions Acknowledgements. The reported study was funded by government subsidy — project name 'Socio-Political and Cultural Development of South Russia's Peoples: Comprehensive Studies in Respective Processes' (state reg. no. AAAA-A19-119011490038-5).

For citation: Okonov B. A. Repression against Kalmykia's Komsomol Activists in the Late 1930s. Mongolian Studies (Elista). 2020. Vol. 12. No. 3. Pp. 384-397. (In Russ.). DOI: 10.22162/2500-1523-2020-3-384-397

\section{Введение}

Комсомол был создан как массовая организация молодежи. Формирование коммунистического союза молодежи проходило в сложных социально-политических и экономических условиях: Гражданская война и бандитизм, голод и разруха. Несмотря на это, комсомольские организации под непосредственным руководством партийных организаций прошли свой организационный период в 1920-е гг. 
С самого начала формирования комсомольских организаций одним из важнейших показателей являлось увеличение количества членов Российского коммунистического союза молодежи (РКСМ) ${ }^{1}$. Сведения о количестве членов были обязательным условием оценки эффективности работы областных комитетов РКСМ. При обкомах были созданы информационно-статистические отделы, которые регулярно фиксировали количество членов и отправляли данные в ЦК РКСМ. Проведение агитационно-пропагандистской работы по набору молодежи в комсомол и выполнению плана по приему превращалось в жесткое давление на секретарей областных комсомольских организаций. В результате широкой компании добровольного вступления в ряды комсомола и активной пропагандистской работы по набору в 1920-е гг. происходил неуклонный рост членов РКСМ.

Вместе с формированием региональных организаций и ростом их количества ЦК ВЛКСМ осуществлял мероприятия по проверке соответствия членов коммунистического союза молодежи предъявляемым к ним требованиям. В 1920-е гг. в русле этих мероприятий по всей стране развернулась борьба с классовым врагом. В рамках проверки работы обкомов ЦК ВЛКСМ требовал обращать самое пристальное внимание на количество батрацкой и рабочей молодежи. Калмыкия имела свою специфику в этом отношении, поэтому для определения и правильной классификации социального происхождения требовалось разрабатывать специальные инструкции. Например, ЦК ВЛКСМ рекомендовал во время обследования Калмыцкой областной организации ВЛКСМ в 1929 г. использовать схему по определению социального состава членов союза, разработанную по материалам обкома ВКП(б). Выявленные представители кулачества, духовенства и другие «контрреволюционные элементы» подлежали исключению из комсомола [НА РК Ф. П-22. Оп. 1. Д. 13. Л. 5об.].

В начале 1930-х гг. в рамках борьбы с голодом ЦК ВКП(б) признал необходимым провести чистку сельских партийных организаций. В октябре 1932 г. Политбюро направило на Северный Кавказ с целью «ускорения хлебозаготовок» чрезвычайную комиссию, которую возглавил Лазарь Каганович [Библиотечка агитатора 1932: 15].

В ноябре 1932 г. в Ростове-на-Дону под руководством Л. Кагановича было проведено совещание секретарей парторганизаций Северо-Кавказского региона, на котором была принята следующая резолюция: «В связи с постыдным провалом плана заготовки зерновых заставить местные парторганизации сломить саботаж, организованный кулацкими контрреволюционными элементами, подавить сопротивление сельских коммунистов и председателей колхозов, возглавляющих этот саботаж» [Трагедия 2001: 549]. В соответствии с этим решением были приняты следующие меры: арест всех «саботажников», всех «социально чуждых и контрреволюционных элементов» и суд над ними по ускоренной процедуре, который должен был обеспечить ОГПУ. В Калмыкии в 1932-1933 гг. к партийной ответственности был привлечен 681 коммунист, т. е. почти каждый третий [Максимов 2004: 129].

\footnotetext{
${ }^{1}$ РКСМ создан 29 октября 1918 г. В 1924 г. ему присвоено имя В. И. Ленина - Российский ленинский коммунистический союз молодежи (РЛКСМ). В марте 1926 г. переименован во Всесоюзный ленинский коммунистический союз молодежи (ВЛКСМ).
} 


\section{История}

В связи с проводимой чисткой в партийной организации было принято решение провести чистку в комсомольских организациях, в том числе и в Северокавказской краевой организации ВЛКСМ. В результате только этой чистки на Кубани было исключено 56,3 \% комсомольцев [Библиотечка агитатора 1932: 23].

Таким образом, с момента основания коммунистические и комсомольские организации на регулярной основе подвергались чисткам. Официально эти меры преподносились как необходимые для улучшения состава, укрепления рядов, повышения активности в строительстве нового общества. Завершая чистку, партийно-государственное руководство страны инициировало организацию в середине 1930-х гг. массовых репрессий.

Цель статьи - рассмотреть процесс репрессий против актива и руководства комсомолом в Калмыкии в 1937 г.

\section{Материалы и методы исследования}

Источниковую базу исследования составили как неопубликованные документы из Национального архива Республики Калмыкия (фонд П-22 - архив Калмыцкого обкома ВЛКСМ), так и опубликованные материалы по данной теме. В работе использованы исторические методы: хронологический и проблемно-хронологический, которые позволили выделить особенности репрессивной политики в отношении комсомольцев Калмыкии. Региональная историография по теме репрессий в Калмыкии достаточно обширна и охватывает ее различные аспекты.

\section{История вопроса}

Первые работы по истории комсомольских организаций Калмыкии стали публиковаться после восстановления автономии и возвращения калмыцкого народа из мест депортации. К 50-летию комсомола Калмыкии была опубликована коллективная монография «Верность комсомольскому знамени», в которой авторы пытались осветить исторический путь областной организации ВЛКСМ. Но следует учесть, что в советский период исследователи рассматривали историю сквозь призму марксистского учения, опирающегося на классовый подход в освещении исторических событий. Поэтому в это время освещалась лишь деятельность комсомола «по очищению своих рядов» от представителей прежних «эксплуататорских» классов [Матлаш, Пинчук, Убушаев 1971].

К 60-летию областной организации ВЛКСМ был выпущен новый сборник документов, подготовленный Калмыцким обкомом ВЛКСМ и партийным архивом Калмыцкого обкома КПСС совместно с учеными-историками. В сборник были включены документы и материалы, выявленные в Центральном архиве ВЛКСМ, архивах Калмыцкого и Саратовского обкомов КПСС, Центральном государственном архиве Калмыцкой АССР и государственном архиве Астраханской области. Материалы третьего раздела сборника содержат документы, относящиеся к хронологическому периоду 1933-1941 гг., и показывают участие комсомола в борьбе с кулацкими элементами, борьбой с халатностью и бюрократизмом в своих рядах [Сборник документов 1978]. Таким образом, в советский период были освещены репрессии по отношению к комсомолу лишь как чистки от «классовых врагов». 
В 2002 г. опубликован сборник документов и материалов по истории возникновения, становления и развития первых молодежных организаций в России. Из представленных в сборнике 200 документов один посвящен террору против членов Калмыцкой организации ВЛКСМ. Впервые было опубликовано письмо Калмыцкого обкома ВЛКСМ «О выполнении решений IV пленума ЦК ВЛКСМ», хранящееся в Центре хранения документов молодежных организаций (ЦХДМО). На IV пленуме ЦК ВЛКСМ, проходившем в августе 1937 г. в Москве, высшие должностные лица страны публично заявили о том, что руководители ВЛКСМ проявили «нетерпимую политическую беспечность и проглядели особые методы подрывной работы врагов» [Русское и советское 2002: 252].

Как указывалось в постановлении IV пленума ЦК ВЛКСМ по докладу А. В. Косарева «О работе врагов народа внутри комсомола», многие из руководящих работников комсомола оказались застигнутыми врасплох, допустили серьезные политические ошибки. Все это вызвало по стране, в том числе и в Калмыкии, волну разоблачений всякого рода «контрреволюционеров, террористов, диверсантов и агентов» в среде комсомола. В письме Калмыцкого обкома ВЛКСМ признавалось наличие контрреволюционной буржуазно-националистической организации, которая вела подрывную работу в комсомоле и нанесла серьезный ущерб советской молодежи. Сообщалось, что в результате в комсомольской организации было разоблачено 40 человек, в том числе 13 человек разоблачены как враги народа из числа руководящих сотрудников обкома ВЛКСМ [Русское и советское 2002: 262].

Необходимо отметить, что в опубликованном письме неправильно указаны фамилии. Например, в первом абзаце письма приводятся фамилии руководителей так называемой «контрреволюционной буржуазно-националистической организации Калмыкии: Дедеев ${ }^{2}$, Торбеев, Отхонов, Кекеев, Чопчаев». Указан Торбеев - правильно: Анджур Пюрбеев, председатель Совета народных комиссаров Калмыцкой АССР. Упомянут Чопчаев - правильно: Араши Чапчаев, первый председатель Калмыцкого ЦИК. В последнем абзаце письма перечислены члены комсомола, которые были разоблачены, изгнаны и отстранены от работы:

- Анькаев Т. - правильно: Ванькаев И. Т., бывший секретарь обкома ВЛКСМ;

- Ахилов П. С. - правильно: Бахилов, бывший 2-й секретарь ОК ВЛКСМ;

- Люмджиев Ар. - правильно: Улюмджиев Арвун, бывший заведующий ОРКОЗ ОК ВЛКСМ;

- Хутов Е. К. - правильно: Пахутов, бывший заведующий ОРКО ОК ВЛКСМ [НА РК. Ф. П-22. Оп. Доп. Д. 2. Л. 1-14].

Значительный вклад в изучение истории репрессий в Калмыкии внес К. Н. Максимов, который на основе многочисленных архивных материалов, статистических данных описал репрессивную политику советского государства и механизм ее реализации на примере Калмыкии в период 1918-1940-е гг. Монография была написана с привлечением новых документальных матери-

\footnotetext{
2 Здесь и далее инициалы не указываются в случае их отсутствия в источнике.

${ }^{3}$ Отдел руководящих комсомольских органов; отдел работы комсомольских организаций.
} 


\section{История}

алов, заметно расширивших отечественную историографию о политических репрессиях, массовом терроре, направленном против крестьянства, интеллигенции, кадров управленческого аппарата, духовенства. В ней также продемонстрировано уничтожение руководящих кадров партии в Калмыкии [Максимов 2004].

Изучением истории депортации калмыцкого народа в 1943 г. занимается В. Б. Убушаев, осветивший один из драматических этапов в истории калмыцкого народа, подвергшегося репрессивным воздействиям со стороны властного режима. В 2007 г. вышла монография «Калмыки: выселение, возвращение и возрождение. 1943-1959 гг.» [Убушаев, Убушаев 2007].

Кроме того, ученые на основе материалов архива Управления ФСБ по Республике Калмыкия раскрыли роль в создании организации Араши Чапчаева крупного государственного и общественно-политического деятеля Калмыкии, обвиненного в создании «контрреволюционной, террористической, троцкистской, буржуазно-националистической организации» в Калмыкии [Убушаев, Шорваев 2008].

Е. Н. Бадмаева рассмотрела на примере Калмыкии отдельные аспекты репрессивной политики в СССР в 1920-1930-х гг. Она раскрыла региональные особенности сталинской репрессивной политики по отношению к партийно-советской и хозяйственной номенклатуре Калмыкии, проследила трагические судьбы высших должностных лиц автономии в годы «Большого террора» [Бадмаева 2017].

Т. Б. Манцаева на основе неопубликованных документов из архива Управления Федеральной службы безопасности по Республике Калмыкия осветила политические репрессии в Калмыкии, где было организовано и сфальсифицировано дело «о т. н. контрреволюционной троцкистско-зиновьевской буржуазно-националистической организации». По данному делу были арестованы руководящие работники во всех областях хозяйства, администрации и партии [Манцаева 2009].

Не умаляя значения имеющейся литературы, следует отметить, что предшествующие исследователи освещали тему в рамках смежных тем, и многие вопросы, касающиеся репрессий калмыцкой комсомольской организации, раскрыты лишь фрагментарно.

\section{Репрессии против комсомола}

В 1930-е гг. начался следующий этап политических репрессий в СССР, пик которых пришелся на 1937 г. В этот период происходили расправы не только над представителями прежних «эксплуататорских» классов, но и над «врагами народа», членами партии с большим стажем, представителями интеллигенции и партийно-советской и хозяйственной номенклатуры на уровне Советского Союза в целом и Калмыкии в частности.

В Калмыкии уже за первые три месяца 1937 г. были «разоблачены враги народа»: председатель главного суда И. И. Ользеев, директор Калмыцкого педагогического техникума В. Ф. Жигадло, директор рыбрабфака Н. Б. Закостынов, директор курорта «Тинаки» Леднев, директор совхоза «Ревдольган» С. Шапкаев, директор Башантинского агротехникума Шукер, заместитель директора рыбзавода «Улан Хальмг» Кузин и др. [Бадмаева 2017: 48]. 
В докладе первого секретаря обкома партии И. Н. Карпова на пленуме Калмыцкого обкома ВКП(б), состоявшемся 27-31 марта 1937 г., прямо отмечалось, что «в республике все еще имеются неразоблаченные троцкисты и иные враги народа», и докладчик призвал присутствовавших к их немедленному разоблачению. На самом пленуме был исключен из партии ряд ответственных партийных и хозяйственных работников: управделами Совнаркома Калмыцкой АССР Э. Х. Отхонов, нарком местной промышленности Э.-А. К. Кекеев, секретарь Сарпинского укома ВКП(б) И. С. Сергеев, первый секретарь обкома ВЛКСМ И. Т. Ванькаев. Все они были сняты с работы и арестованы по различным обвинениям [Бадмаева 2017: 49].

Наряду с партийными, советскими, хозяйственными руководителями в 1937-1938 гг. репрессиям подверглось руководство и комсомольский актив Калмыкии. К 1937 г. в Калмыцкой комсомольской организации находилось 6275 человек (из них 143 коммуниста-комсомольца) [Сборник 1925: 13].

Ha IV пленуме ЦК ВЛКСМ, проходившем в августе 1937 г. в Москве, высшие должностные лица страны публично заявили о том, что руководители ВЛКСМ проявили «нетерпимую политическую беспечность и проглядели особые методы подрывной работы врагов» [Русское и советское 2002: 252]. Все это вызвало по стране, в том числе и в Калмыкии, волну разоблачений всякого рода «контрреволюционеров, террористов, диверсантов и агентов»в среде комсомола.

Веяниям постановления IV пленума ЦК ВЛКСМ вторил отчетный доклад Калмыцкого областного комитета XIV областной конференции ВЛКСМ, проведенной летом 1937 г., где указывалось, что «в Калмыцкой республике существовала контрреволюционная буржуазно-националистическая организация, руководимая врагами народа - Дедеевым, Отхоновым, Кекеевым, Ванькаевым, Пюрбеевым А., Чапчаевым, Цатхланговым и др.» [НА РК. Ф. П-22. Оп. Доп. Д. 2. Л. 1]. В докладе подтверждалось, что исключенный к тому времени «секретарь Обкома ВЛКСМ И. Т. Ванькаев был активным членом буржуазно-националистической организации в Калмыкии. Только вмешательство Областного комитета партии дало возможность разоблачить Ванькаева как врага народа и положить начало решительной борьбе с буржуазно-националистическими элементами в Калмыцком комсомоле и оздоровить руководство Обкома ВЛКСМ и улускомов» [НА РК. Ф. П-22. Оп. Доп. Д. 2. Л. 1].

На XIV областной конференции ВЛКСМ широко обсуждалась деятельность не только секретаря обкома ВЛКСМ И. Т. Ванькаева, но и других членов бюро обкома. К тому времени в бюро Калмыцкого обкома ВЛКСМ состояли Е. К. Пахутов, П. С. Бахилов, Колдаев, Шеринова, Очиров, К. Лиджиев и А. Улюмджиев.

На конференции констатировали, что «в бюро Обкома ВЛКСМ существовала неделовая небольшевистская, затхлая обстановка. Обстановка семейственности, круговой поруки, подмена деловых большевистских отношений между работниками, приятельскими, панибратскими, излишне товарищескими отношениями, основанными на собутыльничестве, обстановка отсутствия большевистской самокритики, обстановка мелкобуржуазной расхлябанности, которые срывали основы большевистского руководства. Это благоприятствовало Ванькаеву и его ставленникам» [НА РК. Ф. П-22. Оп. Доп. Д. 2. Л. 2]. 


\section{История}

Члены бюро обкома Лиджиев Кюлмин и Улюмджиев Арвун были названы «прямыми агентами врагов, подлыми изменниками, предателями» и выведены из состава бюро [НА РК. Ф. П-22. ОП. Доп. Д. 2. Л. 4].

Приближенным, близким и своим человеком «врагов народа» М. Дедеева и А. Пюрбеева на конференции был указан Е. К. Пахутов - к тому времени уже бывший секретарь городского комитета ВЛКСМ. На конференции утверждалось, что «по инициативе Дедеева он премировался во время 15-летия комсомола. Также Пахутов имеет чуждые большевику качества - верхоглядство, зазнайство, бытовое разложение. Пахутов по знакомству и семейному [принципу] подбирал и послал свои кадры на работу в Черноземельский улуском в ВЛКСМ Уланкинова П., Мучкинова и Манушева, которые бросили работу и сбежали, в Западный улус - Ширипова, в Приволжский - Молдавского, Центральный - Точка А.» [НА РК. Ф. П-22. Д. 2. Оп. Доп. Л. 5].

VI пленумом обкома ВЛКСМ Е. К. Пахутов был исключен из состава бюро с объявлением строгого выговора. Но на конференции решение пленума было признано недостаточным, «ибо нет никаких сомнений, что Пахутов работал заодно с врагами, буржуазными националистами, вредил комсомолу Калмыкии» [НА РК. Ф. П-22. Оп. Доп. Д. 2. Л. 15].

На конференции было решено, что необходимо «по-большевистски беспощадно изгнать из комсомольской семьи этих подлых изменников типа Пахутова» [НА РК. Ф. П-22. Д. 2. Оп. Доп. Л. 5]. Так же беспощадно предлагалось отнестись к бывшему члену обкома, председателю совета по делам физкультуры и спорта при Совнаркоме - Х. Кугультинову. Отмечалось, что Х. Кугультинов «проверенный» и «лично преданный человек Ванькаева», который взял его на работу сначала в обком, а потом выдвинул на пост председателя комитета по делам физкультуры и спорта при СНК Калмыцкой АССР. Там «вражеский агент» Х. Кугультинов якобы более года вел по заданию своих «руководителей» вредительскую подрывную работу и за свою «подрывную вредительскую работу» от своего «руководителя» М. Дедеева получил незаслуженную премию под видом активного работника комсомола на 15-летие Калмыцкого комсомола [НА РК. Ф. П-22. Д. 2. Оп. Доп. Л. 6]. Таким образом знакомство и сотрудничество с уже подвергшимся репрессии членом партии и комсомола превращалось теми, кто проводил репрессивную политику, из «пособничества» недостаточно ответственным руководителям во вредительство и подрывную работу.

На VI пленуме обкома ВЛКСМ разбирали и дела других калмыцких комсомольцев.

Бывший второй секретарь обкома П. С. Бахилов был обвинен в том, что в своей работе допускал «политические колебания и неустойчивость» в борьбе за разоблачение врагов народа, а также «угодничал и подхалимничал» перед врагами народа: М. Дедеевым - секретарем обкома ВКП(б), И. Ванькаевым - первым секретарем обкома ВЛКСМ, и «покровительствовал Ванькаеву, Манджиевой, терпимо либерально относился к фактам подрывной работы врагов народа в Калмыцком комсомоле и не помог организации в разоблачении и изгнании этих врагов». Пленум обкома решил, что П. С. Бахилов «активно не помогает организации в разоблачении врагов, буржуазных националистов, 
поэтому он был снят с работы второго секретаря обкома и исключен из бюро» [НА РК. Ф. П-22. Д. 2. Оп. Доп. Л. 7].

Другие члены бюро обкома ВЛКСМ также были обвинены в недостаточной бдительности и «разложении». Так, члены бюро обкома ВЛКСМ Шеринова и Колдаев были обвинены в том, что не проявляли необходимой политической активности в работе бюро обкома, не имели «политической заостренности» в своей работе, «самоустранились от повседневной работы бюро» и не помогали организации как члены бюро в разоблачении националистов и других врагов. Член бюро обкома ВЛКСМ Очиров, за которым признавалось, что он иногда поступал «принципиально» и «правильно», сигнализируя о фактах подрывной работы Ванькаева, все же был обвинен в том, что не только не сумел «принципиально последовательно развиваться до политических высот», но и сам терпимо и либерально относился к обнаруженным им фактам, был подвержен «бытовому разложению» (пьянке). Ему вменялась политическая ответственность за подбор неработоспособных и политически неблагонадежных кадров (Хочиев, Тепкеляев) в Приволжском улускоме [НА РК. Ф. П-22. Д. 2. Оп. Доп. Л. 8].

Признание участия в буржуазно-националистической организации первым секретарем обкома ВЛКСМ И. Т. Ванькаевым привело к снятию с работы десятков комсомольцев. Его «агентами» были признаны: секретарь Центрального улускома Манджиева; заместитель секретаря Приволжского улускома Молдавский, редактор комсомольской газеты «Улан-багчуд» ${ }^{4}$ («Красная молодежь») О. Нормаев, заведующий отделом пионеров обкома Лиджиева; заместитель секретаря Черноземельского улускома Доржина и секретарь этого улускома Авяева [НА РК. Ф. П-22. Д. 2. Оп. Доп. Л. 16].

Решением XIV областной конференции ВЛКСМ эти комсомольцы сняты с работы как «не оправдавшие доверия» организации. С формулировкой «оказавшиеся неработоспособными» также сняты с постов секретарь Приволжского улускома Тепкеляев и заведующий отделом политучебы Саянин, секретарь Западного улускома Какугинов, секретарь Сарпинского улускома Эрднешкиев, заведующий отделом политучебы Западного улускома Болданов и т. д. [НА РК. Ф. П-22. Д. 2. Оп. Доп. Л. 8].

Летом 1937 г. в Калмыкии были проведены отчетно-выборные собрания первичных организаций и улусные конференции ВЛКСМ. Отчетно-выборные собрания положили начало выявлению «врагов народа» на местах и перестройке работы организации по выполнению указаний ЦК ВЛКСМ о коммунистическом воспитании комсомольцев и молодежи. Критика в адрес прежних руководителей улускомов позволила поставить на их места новых людей. Так, в Долбанском и Приволжском улусах на конференциях комсомольцы раскритиковали работу бюро и не допустили в новый состав улускомов ни одного члена старого бюро [НА РК. Ф. П-22. Д. 2. Оп. Доп. Л. 14].

Для широкого обсуждения постановления IV пленума ЦК ВЛКСМ руководством и активом ячеек была обеспечена высокая явка комсомольцев: на собрания первичных организаций явилось всего 4631 чел., или 81,5 \% от общего количества комсомольцев, выступило 2309 чел., или к числу присутствовав-

\footnotetext{
${ }^{4}$ Так в документе. В современной орфографии: «Улан баһчуд».
} 


\section{История}

ших 49,8 \%. По отдельным улусам: в Долбанском улусе явились на собрания 80,7 \% членов, выступили - 65,4 \%, в Лаганском улусе явились 79,5 \%, выступили - 49,0 \% [НА РК. Ф. П-22. Д. 2. Оп. Доп. Л. 15].

В составе улускомов 63,7 \% их членов были вновь пришедшими на комсомольскую работу (из 259 чел. - 165); в составе бюро улускомов новыми их членами являлись 78,7 \% (из 47 чел. - 37); в составе секретарей улускомов вновь пришедших на комсомольскую работы было 87,5 \% [НА РК. Ф. П-22. Д. 2. Оп. Доп. Л. 15].

На проведенных улусных собраниях актива ВЛКСМ и собраниях первичных организаций по проработке постановления IV пленума ЦК ВЛКСМ были выдвинуты обвинения против ряда комсомольских лидеров. Так, были «обнаружены» «скрытые враги народа», которые вели подрывную работу:

«Признание своей вины А. Чапчаевым, секретарем Сарпинского укома ВКП(б) И. С. Сергеевым» послужило основанием для объявления того, что в Сарпинском улусе «орудует шайка буржуазных националистов», которые «ведут подрывную работу в колхозах, срывают воспитание молодежи, проваливают политическую работу среди нее». Как указывалось, «остатки А. Чапчаева ${ }^{5}$, И. С. Сергеева в своей подрывной работе используют метод разжигания родовой борьбы, метод разжигания местнических родовых чувств у отсталой части населения. Так они долгое время ведут борьбу в Алцын-Хуте, Хапчинах и Абганерах. Этим методом долгое время удавалось держать на работе председателя Хапчинского колхоза Болдырева Эренжена. Болдырев - соучастник банды до 1929 г., правая рука Сергеева, расхититель колхозного имущества, проводил в своей работе антигосударственную практику. В этой родовой борьбе участвовали, помогали Болдыреву комсомольцы Тахтинов, Шапшункаев и Коваев. Писали текст письма и проводили собрания бригад на счет сохранения „своего“ Болдырева» [НА РК. Ф. П-22. Оп. Доп. Д. 2. Л. 16]. Местные жители, организовавшие оказание помощи семьям А. Чапчаева и И. С. Сергеева, на конференции были названы «агентами и националистами» [НА РК. Ф. П-22. Д. 2. Оп. Доп. Л. 16].

«Признание участия в буржуазно-националистической организации секретарем обкома ВКП(б) М. Дедеевым» позволило предполагать наличие в Западном улусе «фашистской шайки, действующей вкупе с буржуазными, националистическими элементами», «остатками Дедеева, Карвиновщины, Чимде и прочей своры» [НА РК. Фонд П-22. Оп. Доп. Д. 2. Л. 17]. Бытовая ссора и последовавшая за тем драка в Западном улусе между призывниками Шинфельдского с/совета (немцы) и Яшалтинского сельского совета (русские) с выкриками «Германия вам покажет, как воевать» послужила фактом, который рассмотрен был как подтверждение существования такой шайки [НА РК. Ф. П-22. Оп. Доп. Д. 2. Л. 17].

«Сорванные занятия в школе в Черноземельском улусе» также, по мнению боровшихся за «чистоту» рядов комсомольцев и проведение в жизнь решений IV пленума ЦК ВЛКСМ и VI пленума обкома ВЛКСМ, указывали на «активную работу националистов» и других «врагов народа». Дело было в том, что

5 Так в документе. 
в начале сентября состоялась свадьба учителя Каратаева и дочери «врага народа» Очирова, и тогда же начались занятия в школе. В этот день «отказались от работы» (то есть посетили свадьбу) учитель С. Бадышев, ранее исключавшийся из ВЛКСМ, сын кулака Эдлеев и Пелагея Медведева. Секретарь комитета ВЛКСМ учитель Дорджиев, директор МТС, комсомолец Гаряев, учитель Палухин - сын кулака, Антонов Иван - сын кулака «организовали пьянку» 1-2 сентября, из-за чего были сорваны школьные занятия. Кроме того, «они избили председателя сельского совета Аролдаеву М. и учителя Лиджанова С.» [НА РК. Ф. П-22. Д. 2. Оп. Доп. Л. 17].

На собраниях указывалось, что «по заданию исключенного из партии бывшего председателя Совнаркома А. П. Пюрбеева» в Центральном улусе (в Ики-Буруле) «агентом буржуазных националистов Манджиевым Кару» устраивались специальные вечера, на которых собирались молодежь и старики, рассказывали биографию А. П. Пюрбеева, разучивали песни о нем, сочиняли рассказы о нем. Все это якобы делалось, «чтобы завербовать больше сторонников Пюрбеева», «буржуазных националистов», искусственно поднимая «ложный авторитет» Пюрбеева. Такие же вечера устраивались и в Элисте [НА РК. Ф. П-22. Д. 2. Оп. Доп. Л. 17].

Против Кару Манджиева было выдвинуто обвинение в том, что он писал роман о Пюрбееве по заданию самого Пюрбеева и получал от него деньги и машину для этой цели [НА РК. Ф. П-22. Оп. Доп. Д. 2. Л. 18].

Установленные факты позволили утверждать комсомольцам на XIV конференции о необходимости дальнейшей работы по «искоренению врагов».

При обсуждении решений IV пленума ЦК ВЛКСМ и при проведении районных, городских и областной конференции комсомола в Калмыкии были «разоблачены» как «враги народа» и их «агенты», проводившие «подрывную работу», многие деятели комсомола Калмыкии. Главными из них назывались:

- Манджиев Сангаджи - бывший секретарь Центрального УК, обвиненный в троцкизме;

- Монтаев Борис - бывший заместитель секретаря Сарпинского улускома, сын скотопромышленника, обвиненный и в том, что он сам белый эмигрант;

- Нормаев О. - бывший редактор газеты «Улан-багчуд», брат «контрреволюционера», «буржуазного националиста», обвиненный в том, что на страницах газеты протаскивал антисоветские, контрреволюционные толкования основных вопросов политики партии и правительства;

- Улюмджиев Арвун - бывший заведующий ОРКО ОК, сын кулака-торговца, которому приписывали то, что он - «орграспред Ванькаева»;

- Дорджин Сангадже - бывший заместитель секретаря Черноземельского улускома ВЛКСМ, которому вменили в вину, что он «сын маклера, сам был манджиком в буддийском храме (хуруле), два раза исключался из ВЛКСМ»;

- Лиджиев Кюдмин, «разоблаченный» как «агент врагов» и их ставленник, бывший заведующий пионерским отделом обкома КСМ, выдвинутый на эту работу М. Дедеевым и И. Ванькаевым;

- Кекеев Сандже и Харцхаев - «защитники троцкиста» Закостынова. Харцхаеву было припомнено, что он - сын атамана, расстрелянного красными, а сам был манджиком в хуруле; 


\section{История}

- Манджиев Кару — «националист», «друг врага Даван-Гаря», «агент Дедеева, Пюрбеева, Отхонова», которому вменялось в вину и то, что он - сын скотопромышленника и скрыл это от организации;

- Барванциков Бадма - «агент Чапчаева, Сергеева, буржуазный националист, организатор и вдохновитель родовой борьбы, разжигатель националистических, родовых взглядов», который укрывал факты организации помощи А. Чапчаеву и И. Сергееву;

- Хонинов Николай, обвиненный в том, что он «националист, агент Чапчаева, руководитель организации материальной и моральной поддержки Чапчаеву», был тесно связан с ним, постоянно переписывался, «устраивал семью Чапчаева в Сарепте».

Также были разоблачены работники комсомольской печати - сотрудники областной газеты «Улан-багчуд» ('Красная молодежь') и пионерской газеты «Leninə acnr» ${ }^{6}$ ('Ленинские внучата'). На XIV конференции указывалось, что «пьянками сильно занимаются работники печати и литературы». В редакции газет «враги народа хозяйничали безнаказанно. Финансовое хозяйство развалено, работа с юнкорами запущена, сознательно срывался тиражный план. Редакцией газеты «Улан-багчуд» скрывались материалы юнкоров на счет подрывной деятельности Ванькаева. Это сделано Нормаевым и Мукебеновым» [НА РК. Ф. П-22. Д. 2. Оп. Доп. Л. 20].

Всего в калмыцкой комсомольской организации разоблачено 40 «врагов» и «их пособников», в том числе 13 человек были «разоблачены» как враги народа из руководящих КСМ работников [НА РК. Ф. П-22. Д. 2. ОП. Доп. Л. 19].

Таким образом, руководство партийных и комсомольских органов было отстранено и арестовано по делу т. н. контрреволюционной троцкистской буржуазно-националистической организации.

Весной 1938 г. без суда - административным решением были приговорены постановлением Особого совещания при НКВД СССР И. Т. Ванькаев, С. К. Каляев, Х. Б. Сян-Белгин, С. Манджиев к 8 годам, а К. Э. Эрендженов к 5 годам лишения свободы. Летом 1938 г. осужденных по этому делу было предписано Управлению госбезопасности НКВД Калмыцкой АССР направить с первым отходящим этапом в г. Владивосток в распоряжение начальника Владивостокского отделения Севвостлага НКВД «для отправления на Колыму» [Манцаева 2009: 174].

\section{Выводы}

Политические репрессии в Калмыкии по отношению к комсомольцам в 1930-е гг. были непосредственно связаны с репрессиями партийно-государственной и хозяйственной номенклатуры автономии. Признав свое «участие в буржуазно-националистической организации», члены Калмыцкого обкома ВКП(б) и обкома ВЛКСМ положили начало массовым чисткам в своих рядах. В результате наветов многие комсомольские работники были исключены из ВЛКСМ как «враги народа» и репрессированы. Лишь после ХХ съезда КПСС пострадавшим от культа личности Сталина было возвращено их доброе имя: тяжкие обвинения с них были сняты, они были реабилитированы как в судебном, так и в партийном порядке.

\footnotetext{
${ }^{6}$ Так в документе. В соврем. графике «Ленина ачнр».
} 


\section{Монголоведение • Mongolian Studies • $2020 \bullet$ T. 12 • № 3}

\section{Источники и литература}

Бадмаева 2017 - Бадмаева Е. Н. Политические репрессии по отношению к партийно-государственной номенклатуре и управленческо-хозяйственным работникам в Калмыкии в 1930-х гг. // Вестник Удмуртского университета. Сер. «История и филология». 2017. Т. 27. Вып. 1. С. 47-52.

Библиотечка агитатора 1932 - Очистить ряды Ленинского Комсомола от предателей и изменников / Библиотечка агитатора. Агитмассовый отдел СевКавРайкома ВКП(б). Вып. 21. Ростов н/Д.: Партиздат, 1932. 92 с.

Максимов 2004 - Максимов К. Н. Трагедия народа: Репрессии в Калмыкии. 19181940-е годы. М.: Наука, 2004. 311 с.

Манцаева 2009 - Манцаева Т. Б. О так называемой контрреволюционной троцкистско-зиновьевской буржуазно-националистической организации в Калмыкии // Вестник Тамбовского государственного университета. Гуманитарные науки. История и политология. 2009. Вып. 12 (80). С. 370-374.

Матлаш, Пинчук, Убушаев 1971 - Матлаш В. С., Пинчук Б. Б., Убушаев В. Б. Верность комсомольскому знамени. Элиста: Калм. кн. изд-во, 1971. 251 с.

НА РК - Национальный архив Республики Калмыкия.

Русское и советское 2002 - Русское и советское молодежное движение в документах 1905-1937 гг. / сост. П. П. Александров-Деркаченко. М.: ОМП-Пресс, 2002. 288 с.

Сборник 1925 - Сборник статистических сведений о состоянии РЛКСМ и детдвижения за период с 1 апреля 1924 г. по 1 октября 1925 г. / ЦК РЛКСМ, Стат. подотд. М.: Тип. ЦК РКП (б), 1925. 20 с.

Сборник документов 1978 - Сборник документов и материалов по истории калмыцкой организации ВЛКСМ / сост. З. Б. Очирова, А. О. Тапкина, А. И. Наберухин, В. Б. Убушаев, В. П. Санчиров, А. Н. Буров. Элиста: Калмиздат, 1978. 319 с.

Трагедия 2001 - Трагедия советской деревни. Коллективизация и раскулачивание. 1927-1939. Документы и материалы. В 5 т. (1999-2006)/-под ред. В. Данилова, Р. Маннинга, Л. Виолы. Т. 3. Конец 1930-1933. М.: РОССПЭН, 2001. С. 549-553.

Убушаев, Убушаев 2007 - Убушаев В. Б., Убушаев К. В. Калмыки: выселение, возвращение, возрождение. 1943-1959 гг. Элиста: Изд-во КалмГУ, 2007. 496 с.: ил.

Убушаев, Шорваев 2008 - Убушаев В. Б, Шорваев Э. У. Об обвинениях А. Ч. Чапчаева в контрреволюционной деятельности в 1936-1937 гг. // Вестник Института комплексных исследований аридных территорий. 2008. № 1(1). С. 60-65.

\section{Sources and References}

Badmaeva E. N. Political repressions against the party-state establishment and management and economic workers in Kalmykia in 1930s. Bulletin of Udmurt University. Series History and Philology. 2017. Vol. 27. No. 1. Pp. 47-52. (In Russ.)

Cleansing Leninist Komsomol from Traitors and Betrayers. Ser. 'Propagandist Library'. North Caucasus Committee of All-Union Communist Party (Bolsheviks). Vol. 21. Rostov-on-Don: Partizdat, 1932. 92 p. (In Russ.)

Maksimov K. N. Tragedy of the Nation: Repressions in Kalmykia, 1918-1940s. Moscow: Nauka, 2004. 311 p. (In Russ.)

Mantsaeva T. B. Revisiting a so called counterrevolutionary Trotsky-Zinoviev bourgeoisnationalist organization in Kalmykia. Tambov University Review. Series: Humanities. 2009. No. 12 (80). Pp. 370-374. (In Russ.)

Matlash V. S., Pinchuk B. B., Ubushaev V. B. Remaining Dedicated to the Banner of Komsomol. Elista: Kalmyk Book Publ., 1971. 251 p. (In Russ.)

National Archive of the Republic of Kalmykia.

Aleksandrov-Derkachenko P. P. (comp.) Russian and Soviet Youth Movements: Documents of 1905-1937. Moscow: OMP-Press, 2002. 288 p. (In Russ.) 


\section{История}

Russian Leninist Young Communist League (RLKSM) and Children's Movement: Collected Statistical Reports, 1 April 1924 - 1 October 1925. Central Committee of RLKSM, Statistical Dept. Moscow: Central Committee of Russian Communist Party (Bolsheviks), 1925. 20 p. (In Russ.)

Ochirova Z. B. et al. (comps.) Kalmyk Komsomol (VLKSM) Organization: Collected Documents and Historical Materials. Elista: Kalmizdat, 1978. 319 p. (In Russ.)

Danilov V., Manning R., Viola L. (eds.) Tragedy of Soviet Village: Collectivization and Dekulakization, 1927-1939. Coll. Documents and Materials. In 5 vols. Vol. 3: Late 1930 - 1933. Moscow: ROSSPEN, 2001. Pp. 549-553. (In Russ.)

Ubushaev V. B, Shorvaev E. U. 1936-1937 accusations against A. Ch. Chapchaev of counterrevolutionary activities revisited. Vestnik Instituta kompleksnykh issledovaniy aridnykh territoriy. 2008. No. 1(1). Pp. 60-65. (In Russ.)

Ubushaev V. B., Ubushaev K. V. Kalmyks: Deportation, Return, Revival. 1943-1959. Elista: Kalmyk State University, 2007. 496 p. (In Russ.) 